\title{
A coupled UV photolysis-biodegradation process for the treatment of decabrominated diphenyl ethers in an aerobic novel bioslurry reactor
}

\author{
Yi-Tang Chang ${ }^{1,2}$ (D) $\cdot$ Huei-Chen Chen ${ }^{1} \cdot$ Hsi-Ling Chou ${ }^{1} \cdot$ Hui Li $^{2} \cdot$ Stephen A. Boyd ${ }^{2}$ \\ Received: 1 April 2020 / Accepted: 6 September 2020 / Published online: 28 September 2020 \\ (C) Springer-Verlag GmbH Germany, part of Springer Nature 2020
}

\begin{abstract}
The commercial flame retardant is an emerging contaminant (EC) commonly found in soils and sediments. A coupled UVphotolysis-biodegradation process was used to decompose decabromodiphenyl ether (BDE-209) in clay slurries. A novel bioslurry bioreactor (NBB) was employed in which BDE-209 degradation was maximized by the simultaneous application of LED UVA irradiation and biodegradation by a mixed bacterial culture. The rate of BDE-209 degradation decreased in the order: coupled UV photolysis-biodegradation $\left(1.31 \times 10^{-2}\right.$ day $\left.^{-1}\right)>$ UV photolysis alone $\left(1.10 \times 10^{-2}\right.$ day $\left.^{-1}\right)>$ biodegradation alone $\left(1.00 \times 10^{-2}\right.$ day $\left.^{-1}\right)$. Degradation intermediates detected included hydroxylated polybrominated diphenylethers, partially debrominated PBDE congeners and polybrominated dibenzofuran. The UV-resistant bacterial strains isolated that could utilize BDE-209 as a sole carbon source included Stenotrophomonas sp., Pseudomonas sp., and Microbacterium sp. These strains encoded important functional genes such as dioxygenase and reductive dehalogenases. Continuous UV irradiation during the NBB process affected various biochemical oxidative reactions during PBDEs biodegradation. Simultaneous photolysis and biodegradation in the NBB system described reduces operational time, energy, expense, and maintenance-demands required for the remediation of BDE-209 when compared to sequential UV-biodegradation process or to biodegradation alone.
\end{abstract}

Keywords Coupled UV photolysis-biodegradation · Decabromodiphenyl ether · Novel bioslurry bioreactor · UV-resistant bacterial strains $\cdot$ Polybrominated dibenzofuran

Highlights

- A time, energy, and cost-saving technique using a coupled UV photolysis-biodegradation process for degrading BDE-209 in a novel bioslurry bioreactor.

- Identification of isolated UV-resistant bacterial strains that potentially are able to utilize PBDEs as sole carbon source and the analysis of related functional genes.

- The prediction of a possible pathway for BDE-209 degradation by coupled photolysis-biodegradation.

Responsible Editor: Sami Rtimi

Electronic supplementary material The online version of this article (https://doi.org/10.1007/s11356-020-10753-9) contains supplementary material, which is available to authorized users.

Yi-Tang Chang

ytchang@scu.edu.tw

Stephen A. Boyd

boyds@msu.edu

1 Department of Microbiology, Soochow University, Taipei 11102, Taiwan

2 Department of Plant, Soil and Microbial Science, Michigan State University, East Lansing, MI 48824, USA

\section{Introduction}

Polybromodiphenyl ethers (PBDEs) have been widely used as brominated flame-retardants in many commercial products including textiles, furniture, and electronics. Decabromodiphenyl ether (BDE-209) is the most prevalent congener in commercial PBDE mixtures. This congener was targeted in the elimination annex of the 2017 Stockholm Convention. Because BDE-209 is resistant to environmental degradation via chemical, biological, and photolytic processes, it is considered a persistent organic pollutant (POP). It is released into the environment during production, use, storage, disposal, and recycling, and has become one of the most commonly encountered emerging contaminants (ECs) (McGrath et al. 2017). Soil contamination by PBDEs seems especially prevalent in China and other developing countries. For example, high concentrations of BDE-209 in soils and sediments are encountered at many electronic waste disposal sites in China, including those within the Pearl River Delta region in Guangdong Province, and in industrial areas where BDE-209 is manufactured, as for example Laizhou Bay 
in Shandong Province (Ji et al. 2017). Five electronic waste disposal sites in Guangdong Province were surveyed and found to have BDE-209 concentrations in soil of approximately $200 \mathrm{ng} \mathrm{g}^{-1}$, and four river sediments in Shandong Province were found to contain BDE-209 at levels above $200 \mathrm{ng} \mathrm{g}^{-1}$. A soil sample from Shandong Province contained the highest level of BDE-209, viz. 1,852 $\mathrm{ng} \mathrm{g}^{-1}$.

The toxic effects of BDE-209, which may be manifested in both humans and wildlife, include immunotoxicity, cytotoxicity, neurotoxicity, genotoxicity, mutagenicity, carcinogenicity, and teratogenicity (Segev et al. 2009). Furthermore, PBDEs congeners formed from BDE-209 debromination, such as tetra-BDEs, hepta-BDEs, and bromophenols, have been identified as endocrine disrupting chemicals (EDCs) that adversely affect thyroid hormone regulation, neurodevelopment, and reproductive health in certain animals (Liu et al. 2011). The fathead minnow (Pimephales promelas) exposed to a low dose of BDE-209 ( $3 \mathrm{ng} \mathrm{g}^{-1}$ bw-day) for 28 days showed a $53 \%$ and $46 \%$ decline in total circulating thyroxine (TT4) and 3,5,3'-triiodothyronine (TT3), respectively, while TT4 and TT3 deficits at a higher dose of BDE-209 (300 $\mathrm{ng} \mathrm{g}^{-1}$ bw-day) were $59 \%$ and $62 \%$, respectively. Brain deiodinase activity (T4-ORD) was reduced by about $65 \%$ at both the above doses (Noyes et al. 2013). Exposure of a mammalian (male rat) model to BDE-209 resulted in disruption of thyroid function leading to hypothyroidism; in this case, the underlying mechanisms seemed to involve oxidative stress and perturbations of hypothalamic-pituitary-thyroid axis (Wang et al. 2019). Clearly, treatment systems that achieve complete bio-mineralization of BDE-209 are needed to eliminate the adverse effects of BDE-209 on human and ecosystem health.

A number of treatment systems involving coupled photolysis and biological processes have been developed with the goal of enhancing the removal of refractory aromatic compounds from industrial wastewater. For example, $200 \mathrm{mg} \mathrm{L}^{-1}$ of Reactive Black 5 (RB5) azo dye A in textile wastewater was shown to be degraded by such a coupled process $\mathrm{TiO}_{2}$ and 247.3-nm UVC irradiation and aerobic biodegradation (Shan 2013). Cleavage of aromatic rings in RB5 occurred to a significantly degree after $2 \mathrm{~h}$ of illumination, and approximately $60 \%$ COD removal was achieved during aerobic biodegradation by a single strain of Pseudomonas aeruginosa. Similarly, benzotriazole decomposition was achieved using a coupled process consisting of 254-nm UV irradiation (light intensity of $2.12 \mathrm{~mW} \mathrm{~cm}^{-1}$ ) and aerobic biodegradation by an enrichment of benzotriazole-degrading bacteria; a rate constant of $\left.1.39(\mu \mathrm{m} \mathrm{mol} \mathrm{L})^{-1}\right)^{0.34} \mathrm{~h}^{-1}$ was reported (Shan et al. 2017). In contrast to these examples of contaminant removal from wastewater, few studies have focused on using coupled photolysis-biodegradation process for the degradation of POPs/ECs present in soil slurries.
Aerobic bioslurry reactors (ABRs) have been used to remediate POPs in contaminated soil/water slurries. The effective removal of POPs is achieved when complete mixing occurs in an ABR; under such circumstances, PAHs and similar aromatic chemicals have been shown to be biodegraded successfully (Yu et al. 2019a). However, the cleanup of PBDEcontaminated soil/sediment using ABRs presents difficult reactor design challenges if the requirements are rapid remediation times and low cost. An alternative process for remediating PBDE-contaminated soils is proposed in this study, namely the simultaneous coupling of UV photolysis and biodegradation. As a first step toward our goal of treating contaminated soils, montmorillonite clay was selected for study since clays are major component geosorbents found in most soils. A novel bioslurry bioreactor (NBB) that uses coupled UV photolysis and biodegradation is proposed to accelerate BDE-209 removal. UV-resistant bacteria capable of degrading BDE-209 were used in this NBB system. We quantified the major organic decomposition intermediates, as well as the bromide anion, present during the biodegradation of BDE-209 by this coupled photolysis-biodegradation process. The bacterial strains present were evaluated to determine if they are able to utilize PBDEs as a sole carbon source. The RNA expression levels of specific functional genes involved in BDE-209 degradation were measured using PCR and specific primers; these included various ring-cleavage dioxygenases and dehalogenases. Finally, a pathway for BDE-209 degradation in the NBB system is proposed.

\section{Materials and methods}

\section{Chemicals}

BDE-209 with a purity greater than $98 \%$ (Alfa aesar, Germany, 99\% purity) was used to prepare the BDE-209contaminated sediment, and as the sole carbon substrate when assessing the status of the BDE-209-biodegrading bacteria. A standard solution of BDE-209, dissolved in isooctane-toluene $(8: 2, \mathrm{v} / \mathrm{v})$, was used for the GC/MS analysis. A standard solution consisting of 38 PBDEs (Cambridge Isotope Laboratories, Inc., USA, 99\% purity) and BDE-15 (Merck, Germany, 99\% purity) was used for the bacterial utilization analysis. All organic solvents, including n-hexane and acetone, were of GC grade with a purity of $>99.9 \%$. All other chemicals were reagent grade with a purity of $>99 \%$. The Milli-Q water (> $18 \mathrm{M} \Omega \mathrm{cm}$ ) used in this study was obtained from a Millipore water purification system.

\section{Sorbent and BDE-209-biodegrading bacteria}

Ca-montmorillonite (clay) was selected as a representative soil geosorbent for use in the sorbent/water slurry system. The clay 
was used to eliminate the confounding influence of soil organic matter (SOM), present in surface soils and to a much lesser extent in subsoils on UV photolysis and biodegradation. Table S1 shows the physical-chemical characteristics of clay, which was purchased from the Clay Minerals Society, Purdue University, USA. The UV-resistant mixed bacterial culture came from a PBDEs-contaminated sediment collected from the Da-An River, Taiwan; this culture has previously been identified as having the ability to biodegrade BDE-209 and other PBDEs (Chang et al. 2019).

\section{Design of the NBB}

The NBB was designed to carry out an integrated process that simultaneously combined a UV-resistant mixed bacterial culture that was able to utilize BDE-209 as sole carbon source with UV photolysis. Continuous UV radiation is able to generate significant numbers of free radicals and these are able to breakdown the chemical structure of BDE-209 and related other intermediates. BDE-209 biodegradation can also occur at the same time. Figure 1 shows the NBB design that combines UV photolysis with a biological process for the treatment of ECs. The NBB was modified from an original bioreactor that had a sequential UV photolysis and biological processes for BDE-209 treatment and had been used in our previous study (Chang et al. 2020). The NBB consists of two reactors made up of different materials, namely a glass outer reactor and a quartz inner tank. The volume of the inner tank and the outer tank was $4924 \mathrm{~cm}^{3}$ and $330 \mathrm{~cm}^{3}$, respectively. A number (72) of 365-nm LED-UV light lamps ( $45 \times 45$ mil HIPOWER UV-LED CHIP, Advanced Optoelectronic Technology Inc., Taiwan) were fixed onto four aluminummade cooling fins and these were distributed evenly within the inner tank. UV light is able to easily penetrate the quartz wall and enter the clay/water system. The energy intensity of UV irradiation at the outer surface of quartz inner tank was measured and found to be in the range 0.58 to $0.97 \mathrm{mw} \mathrm{cm}$. The clay/water system was added separately into the space between inter tank and outer tank, which has an effective volume of $2598 \mathrm{~mL}$. An overhead mixer with an PTFE stirrer was set up in the tank to allow complete mixing and to promote aerobic conditions.

\section{The coupled photolysis-biological process for BDE- 209 treatment within the NBB}

A coupled UV photolysis-biodegradation process for BDE209 treatment was initiated by adding the Da-An bacterial community into BDE-209-contaminated clay/water system inside the NBB. Complete mixing was achieved using a 280-rpm stirring rate for 140 days; during this time, LED UVA lights were used to provide a steady energy intensity. The method of creating the BDE-209-contaminated clay/ water system was such that it resulted in clay theoretical containing $25 \mathrm{mg} \mathrm{kg}^{-1} \mathrm{BDE}-209$ in mineral salt basal (MSB); this procedure was described in our previous study (Chang et al. 2020). The ratio of the clay/water system was designed to give a ratio of $2 \mathrm{~g}: 25 \mathrm{~mL}$. The experiments consisted of the following: (1) coupled UV photolysis-biodegradation; (2) UV photolysis alone; and (3) biodegradation alone in an absolutely dark environment. Two controls were included; these were the no treatment control (control 0 ) and biodegradation using a culture sterilized with $1 \% \mathrm{NaN}_{3}$ (control 1). The $\mathrm{pH}$ values and ORP values of the slurries were measured and averaged $7.32 \pm 0.21$ (the range of 7.22-7.52) and $218 \pm 26 \mathrm{mV}$ (the range of 188-244 mV), respectively, during experiments.

\section{Analytical methods}

\section{BDE-209 concentration analysis and metabolites identification}

A detail procedure of BDE-209/metabolites analysis in the bioslurry was carried out and this was based on the one used in our previous study (Chou et al. 2016). Ultrasound-assisted extraction from the bioslurry was selected as sample pretreatment when carrying out GC analysis of BDE-209. The concentration of BDE-209 was measured by GC using a pulsed discharge electron capture detector. Possible intermediates detected using the GC/MS full scan mode were identified by prediction, but were not quantified. The $\mathrm{m} / \mathrm{z}$ profiles of the metabolites were identified using the GC/MS spectra databases in the NIST 17 library.

\section{Anion analysis}

Bromide (Br) was measured during the coupled BDE-209 UV photolysis/biodegradation process by ion chromatography (Metrohm 883, Switzerland) using an autosampler (Metrohm 863 Switzerland), and a conductivity detector. Samples of supernatant liquid were separated by high-speed centrifugation, filtered through a $0.22-\mu \mathrm{m}$ nylon filter, and then measured immediately. The retention times within the ion chromatographic profiles were $8.29 \mathrm{~min}$.

\section{Bacterial strains and their utilization of PBDEs as sole carbon resource}

Bacterial strains capable of using BDE-209 or other PBDEs as sole carbon source were isolated during BDE-209 biodegradation in the clay/water system. To do this, $10 \mathrm{~mL}$ of the sorbent/water mixture on day 43, 74, 105, and 140 was collected and subjected to 10 -fold serial dilution. Next $0.2 \mu \mathrm{L}$ of inoculum was spread on purified agar plates made containing $20.0 \mu \mathrm{g} \mathrm{L}^{-1}$ BDE-209 as sole carbon source plus MSB. To avoid bacterial strains that are able to utilize the organic 
Fig. 1 Schematic diagram of the NBB used for coupled UV photolysis-biodegradation: a the design of the NBB; $\mathbf{b}$ a top-down view; $\mathbf{c}$ the design of the $365-\mathrm{nm}$ LED UV-lights, which are fixed to the cooling fines (a)

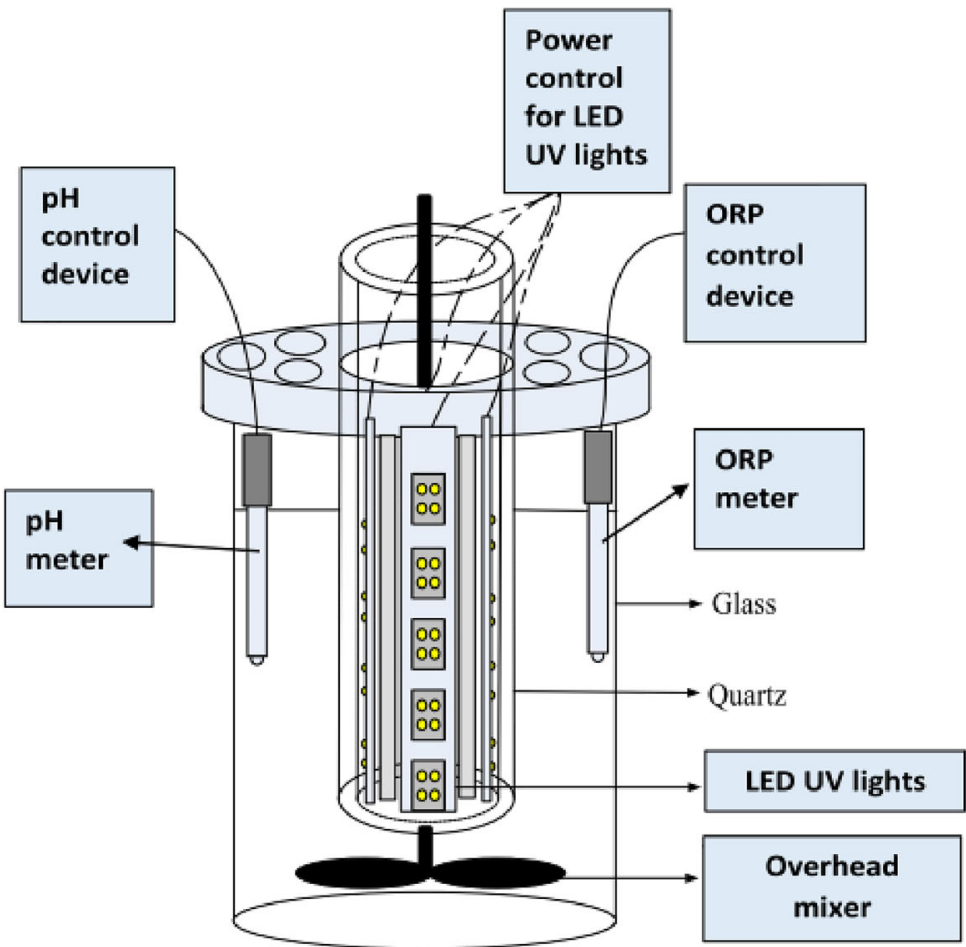

(b)

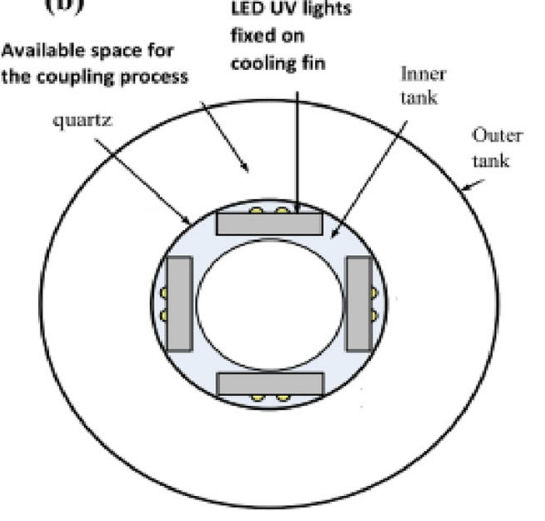

(c)

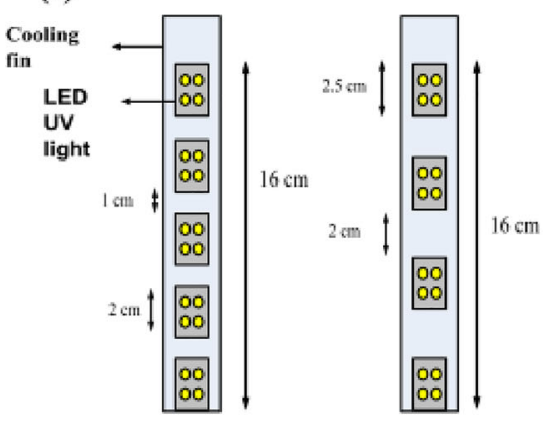

residues present in agar as a carbon source, purified agar was obtained by washing the agar powder with Milli-Q water at least three times before medium preparation. Pure stains, as single colonies, were identified after incubation at $25^{\circ} \mathrm{C}$ for 14 days. These isolated strains were confirmed as being able to grow well on BDE-209-MSB agar plates by the streak method technique and this streaking was repeated at least 35 times. Finally, these strains were identified by Mission Biotech Company (Taiwan) based on the V1-V8 domain sequences of their 16S rDNA regions.

A Biolog MT2 microplate (Hayward, CA, USA)-based assay was used for the rapid identification and evaluation of the ability of a given bacterial strain to utilize PBDEs as a sole carbon substrate. Each Biolog MT2 microplate well was created as a sole carbon source substrate well using MSB; in addition, an equal concentration of tetrazolium violet dye, which is sensitive to the oxidation of a carbon source and to bacterial respiration, was added (Taha et al. 2015; Chang et al. 2020). Different types of PBDEs, namely BDE-209 (25.0 $\mu \mathrm{g}$ $\left.\mathrm{L}^{-1}\right)$, BDE-15 (25.0 $\left.\mu \mathrm{g} \mathrm{L}^{-1}\right)$, and a mixture of 38 PBDE congeners, including mono-BDE, di-BDE, tri-BDE, tetra-BDE, penta-BDE, hexa-BDE, and hepta-BDE were selected as the carbon sources. Table $\mathrm{S} 2$ shows the concentrations of mixed PBDE congeners used in the Biolog MT microplates and these had the range 5.0-12.5 $\mu \mathrm{g} \mathrm{L}^{-1}$. The microplate wells were then inoculated with $150 \mu \mathrm{L}$ of each isolated bacterial strain, which gave a bacterial density or $\mathrm{OD}_{590}$ of between 0.2 and $0.3,10^{7}$ $\mathrm{CFU} \mathrm{mL}{ }^{-1}$ on $\mathrm{R} 2 \mathrm{~A}$ agar; the incubation was carried out at 30 ${ }^{\circ} \mathrm{C}$ in the dark for $48 \mathrm{~h}$. Positive and negative controls for bacterial respiration, using the Biolog MT2 microplate wells, were set up for each isolated strain and contained $25.0 \mu \mathrm{g} \mathrm{L}^{-1}$ glucose-MSB and MSB, respectively. The OD value of each 
microplate well was measured using an ELISA Reader at 590 $\mathrm{nm}$. A positive response, namely the ability to carry out BDE209 biodegradation, was assessed using the equation (Sample $\mathrm{OD}_{590}$ - Negative control $\mathrm{OD}_{590}$ ) and this involved measuring the purple color present in the Biolog MT2 wells. Four levels of BDE-209 utilization were defined based on the relative $\mathrm{OD}_{590}$ values (see above) obtained in this study; these were very strong $(\geq 0.4)$, strong $(0.3-0.4)$, medium $(0.1-0.3)$, and weak $(<0.1)$.

\section{Detection of genes in the isolated identified bacteria encoding functional enzymes related to BDE-209 biodegradation}

Genomic DNA from each strain was assessed in order to detect the presence of genes encoding functional enzymes related to BDE-209 biodegradation. Table 1 lists the published primer pairs that were used to detect the following functional genes; these genes are likely to be involved in BDE-209 biodegradation. One target, dioxygenases, are able to carry out benzene ring-cleavage reactions under aerobic condition; these enzymes include catechol 2,3-dioxygenses (EC 1.3.11.2, C23O), aromatic ring hydroxylating dioxygenase (ARHD), and rieske iron-sulfur dioxygenases (Rf). In addition, reductive dehalogenases that carry out biological debromination under aerobic condition were also screened for, namely Rdha and Rdase. TCEse and PceA were used as the negative control of biological debromination under strict anaerobic condition. The PCR reagents used for the reaction were $2 \mu \mathrm{L}$ purified genomic DNA, $1.5 \mu \mathrm{L}$ each of the primers $(10 \mu \mathrm{M})$, and $5 \mu \mathrm{L}$ of the $5 \times$ PCR master mix in the kit (Gene Mark, Taiwan); these were added to a tube together with 15 $\mu \mathrm{L}$ of sterilized Milli-Q water. Finally, the PCR amplification products were identified by $1 \%$ agarose gel electrophoresis.

\section{Results}

\section{BDE-209 concentration and bacterial numbers in the NBB}

Degradation of BDE-209 in the NBB over time is shown in Fig. 2. The coupled UV photolysis-biological process removed BDE-209 effectively. The concentration of BDE-209 decreased from $24.43 \pm 1.33 \mathrm{mg} \mathrm{kg}^{-1}$ to $0.43 \pm 0.07 \mathrm{mg} \mathrm{kg}^{-1}$ over 84 days using the coupled process. In comparison, the rate of BDE-209 degradation by the UV photolysis process alone was reduced compared to the coupled process, but faster than biodegradation alone. Specifically, the concentration of BDE-209 decreased from $25.09 \pm 3.95 \mathrm{mg} \mathrm{kg}^{-1}$ to $0.06 \pm$ $0.02 \mathrm{mg} \mathrm{kg}^{-1}$ after 98 days using UV photolysis alone, while the concentration of BDE-209 decreased from $26.17 \pm$ $2.32 \mathrm{mg} \mathrm{kg}^{-1}$ to $0.27 \pm 0.09 \mathrm{mg} \mathrm{kg}^{-1}$ after 112 days using biodegradation alone. Previously, the biodegradation kinetics of BDE-209 using a clay/water system was shown to be firstorder (Chou et al. 2016). The first-order rate constant $(k)$ for

Table 1 The primers used for DNA amplification of the various function genes present during BDE-209 degradation

\begin{tabular}{|c|c|c|c|c|c|c|}
\hline No. & $\begin{array}{l}\text { Functional genes } \\
\text { (abbreviation) }\end{array}$ & Primers & $\begin{array}{l}\text { Primer } \\
\text { sequence } \\
\left(5^{\prime} \rightarrow 3^{\prime}\right)^{\text {a }}\end{array}$ & $\begin{array}{l}\text { Position } \\
\text { (bp) }\end{array}$ & $\begin{array}{l}\text { PCR } \\
\text { annealing } \\
\text { temp. }\left({ }^{\circ} \mathrm{C}\right)\end{array}$ & References \\
\hline 1 & $\begin{array}{l}\text { Aromatic ring hydroxylating } \\
\text { dioxygenases }(\mathrm{C} 23 \mathrm{O})\end{array}$ & $\begin{array}{l}\text { C23Or } \\
\text { C23Of }\end{array}$ & $\begin{array}{l}\text { CCAGCAAACACCTCGTTGCGGTTGCC } \\
\text { AAGAGGCATGGGGGCGCACC } \\
\text { GGTTCGATCA }\end{array}$ & 450 & 53 & $\begin{array}{l}\text { Alfreider et al. } \\
2003\end{array}$ \\
\hline 2 & $\begin{array}{l}\text { Aromatic ring hydroxylating } \\
\text { dioxygenases (ARHD) }\end{array}$ & $\begin{array}{l}888 \mathrm{f} \\
300 \mathrm{r}\end{array}$ & $\begin{array}{l}\text { TGCASSTWTCACGGSTGG } \\
\text { CTCGACTCCGAGCTTCCAGTT }\end{array}$ & 340 & 49 & $\begin{array}{l}\text { Kitagawa et al. } \\
2001\end{array}$ \\
\hline 3 & $\begin{array}{l}\text { Rieske iron-sulfur } \\
\text { motif (Rf) }\end{array}$ & $\begin{array}{l}\text { Rf1 } \\
\text { Rr1 }\end{array}$ & $\begin{array}{l}\text { AGGG } \\
\text { ATCCCCANCCRTGRTANSWRCA } \\
\text { TGTTCCCGAACTTGTCCTTC }\end{array}$ & 700 & 55 & $\begin{array}{l}\text { Kumar et al. } \\
2005\end{array}$ \\
\hline 4 & $r d h A$ dehalogenation (RdhA) & $\begin{array}{l}\text { RRf2 } \\
\text { B1r }\end{array}$ & $\begin{array}{l}\text { SHMGBMGWGATTTYATGAARR } \\
\text { CHADHAGCCAYTCRTACCA }\end{array}$ & $1,500-1,700$ & 49 & $\begin{array}{l}\text { Krajmalnik-Brown } \\
\text { et al. } 2004\end{array}$ \\
\hline 5 & $\begin{array}{l}\text { Reductive dehalogenase for } \\
\text { dehalogenation of Dehalobacter } \\
\text { (RDase) }\end{array}$ & $\begin{array}{l}179 \mathrm{f} \\
1007 \mathrm{r}\end{array}$ & $\begin{array}{l}\text { TGTATTGTCCGAGAGGCA } \\
\text { ACTCCCATATCTCTACGG }\end{array}$ & 830 & 53 & $\begin{array}{r}\text { Schlötelburg } \\
\text { et al. } 2002\end{array}$ \\
\hline 6 & $\begin{array}{l}\text { TCE dehalogenation of } \\
\text { Dehalococcoides (TCEse) }\end{array}$ & $\begin{array}{l}\text { TCEsef } \\
\text { TCEser }\end{array}$ & $\begin{array}{l}\text { GGTAATACGTAGGAAGCAAGCG } \\
\text { CCGGTTAAGCCGGGAAATT }\end{array}$ & 1,400 & 60 & $\begin{array}{l}\text { Holmes et al. } \\
2006\end{array}$ \\
\hline 7 & pce $A$ dehalogenation (PceA) & $\begin{array}{l}\text { SpDr1f } \\
\text { SpDr1r }\end{array}$ & $\begin{array}{l}\text { CGTTGGACCTATTCCACCTG } \\
\text { CAAGAACGAAGGCAATCACA }\end{array}$ & 199 & 53 & $\begin{array}{l}\text { Suyama et al. } \\
2002\end{array}$ \\
\hline
\end{tabular}

a: Degenerate nucleotides positions: $\mathrm{R}=\mathrm{A}$ or $\mathrm{G} ; \mathrm{K}=\mathrm{G}$ or $\mathrm{T} ; \mathrm{M}=\mathrm{A}$ or $\mathrm{C} ; \mathrm{S}=\mathrm{C}$ or $\mathrm{G} ; \mathrm{W}=\mathrm{A}$ or $\mathrm{T} ; \mathrm{Y}=\mathrm{C}$ or $\mathrm{T} ; \mathrm{B}=\mathrm{C}, \mathrm{G}$ or $\mathrm{T} ; \mathrm{D}=\mathrm{A}, \mathrm{G}$ or $\mathrm{T} ; \mathrm{V}=\mathrm{A}, \mathrm{C}$ or $\mathrm{G} ; \mathrm{H}=\mathrm{A}, \mathrm{C}$ or $\mathrm{T}$ 


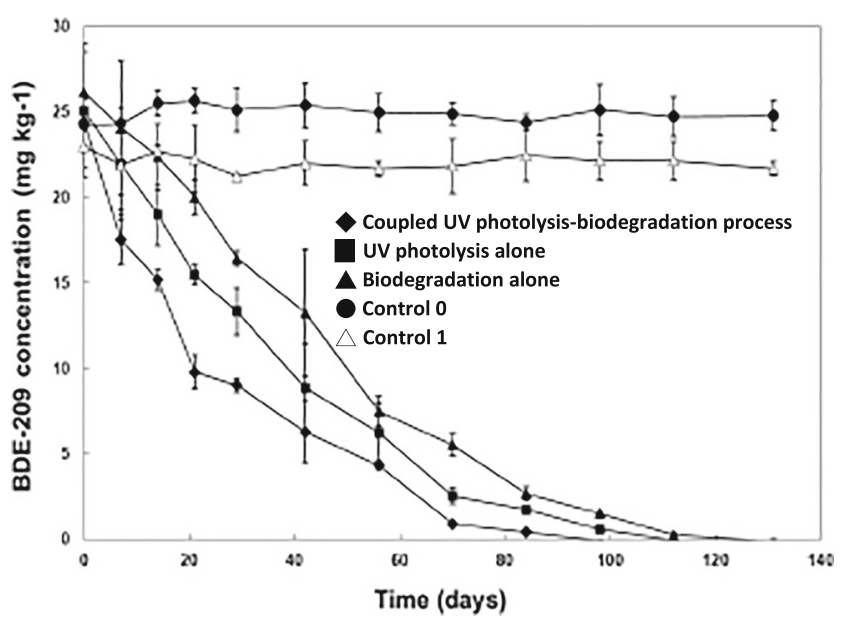

Fig. 2 BDE-209 degradation by coupled UV photolysis-biodegradation in an NBB. Control 0: no treatment; Control 1: biodegradation process only treated with $1 \% \mathrm{NaN}_{3}$ (sterilization)

BDE-209 degradation was found to be $9.3 \times 10^{-3}$ day $^{-1}$ for the Da-An bacterial-mixed culture. The first-order-rate constants for BDE-209 degradation in the present study decreased in the order coupled UV photolysis-biodegradation process $(1.31 \times$ $10^{-2}$ day $\left.^{-1}, r^{2}=0.9972\right)>\mathrm{UV}$ photolysis alone $\left(1.10 \times 10^{-2}\right.$ day $\left.^{-1} ; r^{2}=0.9952\right)>$ biodegradation alone $\left(1.00 \times 10^{-2}\right.$ day $^{-1}$, $\left.r^{2}=0.9684\right)$.

Changes in bacterial populations over time were estimated by platting samples on agar containing BDE-209 as sole carbon; samples from the NBB obtained during the coupled UV photolysis-biodegradation process and biodegradation alone were compared in Fig. 3. The average number of bacteria present during the coupled UV photolysis-biodegradation process was lower than during the biodegradation process alone. The number of bacteria present during the coupled UV photolysisbiodegradation process decreased from $1 \times 10^{7} \mathrm{CFU} \mathrm{mL}^{-1}$ on day 0 to $3.8 \times 10^{4} \mathrm{CFU} \mathrm{mL}^{-1}$ on day 28 . The number of bacteria present then increased to a high of $2.6 \times 10^{6} \mathrm{CFU} \mathrm{mL}^{-1}$ on day 101 , which was followed a second decrease to $7.8 \times 10^{4} \mathrm{CFU}$ $\mathrm{mL}^{-1}$ on day 120. A similar trend was found for biodegradation alone, which decreased from $1 \times 10^{7} \mathrm{CFU} \mathrm{mL}^{-1}$ on day 0 to a low of $1.8 \times 10^{5} \mathrm{CFU} \mathrm{mL}^{-1}$ on day 42 , followed by a maximum of $8.9 \times 10^{6} \mathrm{CFU} \mathrm{mL}^{-1}$ on day 72 and a second decrease to 2.1 $\times 10^{6} \mathrm{CFU} \mathrm{mL}^{-1}$ on day 120 .

\section{Metabolite analysis}

Degradation of BDE-209 by photolytic reactions and microbial biodegradation in the NBB involved cleavage of the aromatic ring, chemical/biological debromination and hydroxylation. The major groups of intermediates resulting from the coupled UV photolysis-biological process include (1) hydroxylated PBDEs (OH-PBDEs), e.g., 2-bromo-3, 5dimethoxybenzyl alcohol; (2) debrominated PBDE congeners, e.g., BDE-99 and BDE-47; and (3) polybrominated dibenzofurans (PBDFs) such as 2,8-dibromodibenzofuran and 4-bromo-dibenzofuran (Table S3), in addition to the bromide (Fig. 4). The concentration of bromide, generated from BDE-209, in the coupled process increased from $23.50 \mathrm{mg} \mathrm{L}^{-1}$ on day 84 to $43.74 \mathrm{mg} \mathrm{L}^{-1}$ on day 131 (total 48 days). Compared to the coupled process, the change in concentration (from day 84 to day 131) of bromide was higher with UV photolysis alone, increasing from 23.06 to $53.53 \mathrm{mg} \mathrm{L}^{-1}$, and lower under biodegradation alone, increasing from 22.96 to only $29.90 \mathrm{mg} \mathrm{L}^{-1}$. These results suggest that both chemical and biological debromination of BDE-209 occur during the coupled NBB process. The rate of bromide generation, derived using a two-variables liner equation from day 84 to day 131, from BDE-209 degradation in the NBB decreased in the order UV photolysis alone $\left(0.63 \mathrm{mg} \mathrm{L}^{-1} \mathrm{day}^{-1}\right)>$ coupled UV photolysis and biodegradation $\left(0.42 \mathrm{mg} \mathrm{L}^{-1}\right.$ day $\left.^{-1}\right)>$ biodegradation alone $\left(0.14 \mathrm{mg} \mathrm{L}^{-1}\right.$ day $\left.^{-1}\right)$.

\section{Identification of various bacterial genera present in the NBB}

Bacterial strains isolated and their ability to utilize PBDE congeners during the coupled UV photolysis-biodegradation process are summarized in Table 2 . Thirty-seven single colonies grew on agar plates containing BDE-209 as the sole carbon source, indicating that these strains had the ability to biodegrade PBDEs. The bacterial isolates include (1) Pseudomonas spp.: Strain No. UV-D, UV-H, UV-I and UV-J; (2) Microbacterium spp.: Strain No. UV-A, UV-C and UV-E; (3) Stenotrophomonas spp.: Strain No. UV-F and UV-G; and (4) Paracoccus yeei: Strain No. UV-B. Of these, six bacterial strains, consisting of four Pseudomonas spp. (Strain No. UV-D, UV-I, UV-J and UV-K) and two Microbacterium spp. (Strain No. UV-A and UV-C), were found to have "very strong" abilities to utilize BDE-209 as a sole carbon source

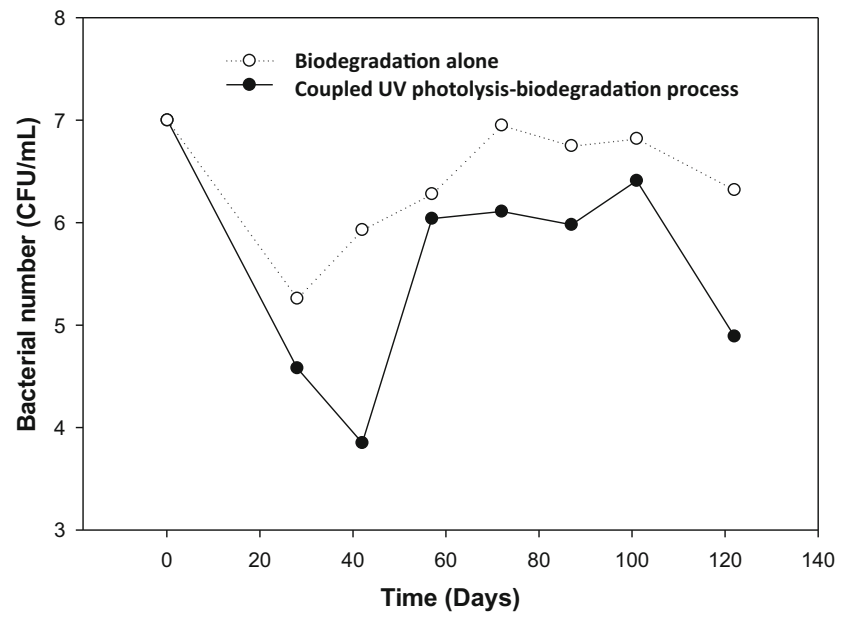

Fig. 3 The number of bacteria present during BDE-209 degradation by coupled UV photolysis-biodegradation in the NBB as measured by bacterial counts on BDE-209 agar plates. $Y$ axis is a log scale 
Fig. 4 Bromide concentration released in the NBB by coupled UV photolysis-biodegradation process used for the treatment of BDE-209

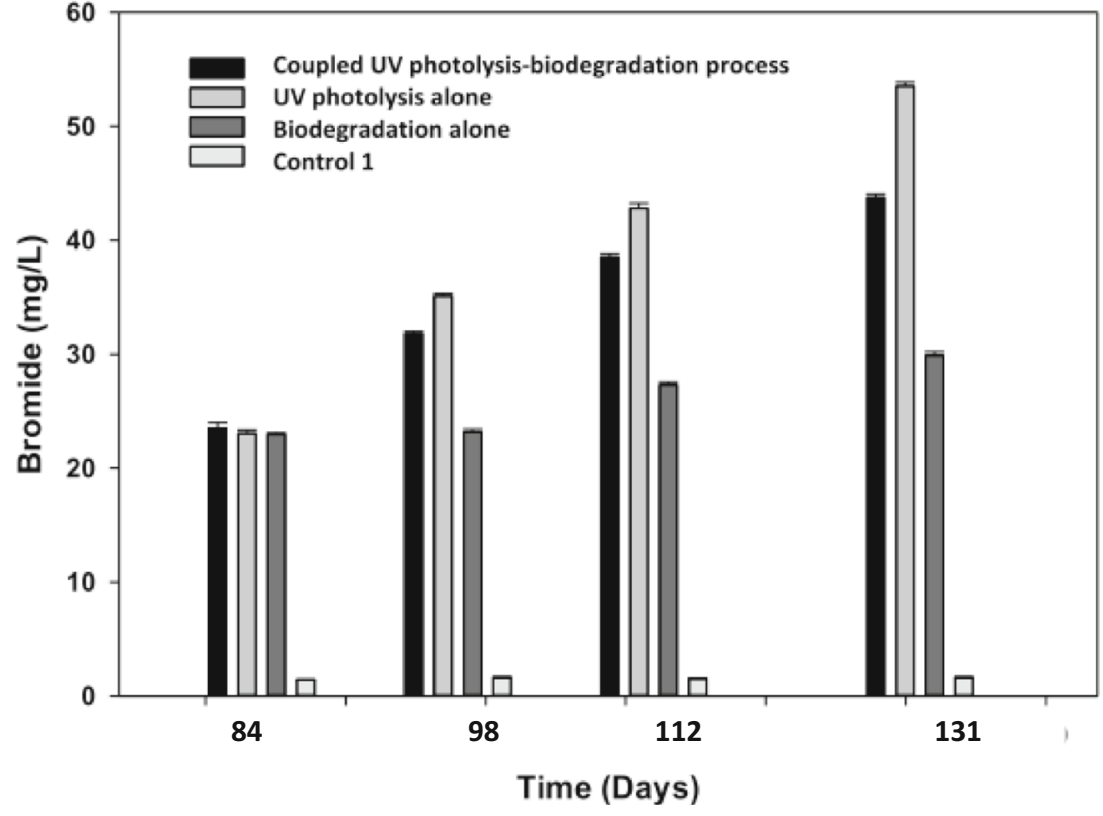

(Table 2). One Pseudomonas sp. (Strain No. UV-J) had a strong ability to utilize BDE-15 as sole carbon source. Two Pseudomonas spp. (Strain No. UV-J and UV-K) were able to utilize strongly a defined mixture of 38 PBDE congeners as carbon sources. Figure S1 shows the phylogenetic trees of the identified bacteria based on their 16S rRNA gene sequences. Four bacterial species were identified, i.e., Paracoccus yeei, Pseudomonas geniculate, Microbacterium laevaniformans, and Pseudomonas stutzeri which are known to be widely distributed in PBDE/ECs-contaminated soil (Chou et al. 2013; Sowada et al. 2014; Wu et al. 2018).

\section{The functional genes associated with BDE-209 bio- degradation present in the isolated bacterial strains}

The results for the PCR-based detection of specfic functional genes related to BDE-209 biodegradation in total genomic DNA extracts from the NBB are shown in Fig. S2. Table 2 shows RNA expression of the specific functional genes related to BDE-209 biodegradation in the various isolated bacterial strains. There were positive signals for three dioxygenases (C23O, ARHD and Rf) and two dehalogenases (RdhA and Rdases) in eight bacterial strains isolated from the coupled UV photolysis-biodegradation process. There was no signal present for the negative control (TCEse and PceA primers) in any of the bacterial strains tested. The UV-F strain showed the most positive responses, having five functional genes (C23O, ARHD, Rf, RdhA and Rdase) present. The UV-A and UV-K stains gave positive signals for three functional genes (C23O, ARHD, and RdhA). No signals were detected for any of the selected genes in three of the isolated strains (Strain No. UV-B, UV-C, and UV-E). Signals also were present for dioxygenases. These were $\mathrm{C} 23 \mathrm{O}$ (eight strains: UV-A,
UV-D, UV-F, UV-G, UV-H, UV-I, UV-J, UV-K), ARDH (three strains: UV-A, UV-F, and UV-K), and Rf (three stains: UV-D, UV-F, and UV-G). Five Pseudomonas spp. (Strain No. UD-D, UV-H, UV-I, UV-J and UV-K), two Stenotrophomonas spp. (Strain No. UV-F and UV-G), and one Microbacterium sp. (Strain No. UV-A) were shown to express the $\mathrm{C} 23 \mathrm{O}$ gene. Positive signals for the dehalogenases RdhA and Rdase were found for six bacteria strains. Specifically, six bacterial strains (UV-A, UV-F, UV-H, UVI, UV-J, and UV-K) were positive for RdhA in their genomic DNA, while only one strain (UV-F) was positive for Rdase.

\section{Discussion}

\section{Advantages of the NBB coupled UV photolysis- biodegradation process}

The coupling of UV-photolysis with biodegradation treatment in a NBB system has been shown here to be more effective at removing BDE-209 compared to biodegradation alone. There are several practical design advantages to the NBB for future use in soil remediation. First, UV photolysis commences instantly and at a uniform level once the LED UV lights are activated, and the intensity of exposure is easily measured at the surface of the inner quartz tank. The use of LED UV lamps reduces the amount of heat generated and saves significant amounts of energy compared to conventional UV light (Chang et al. 2020). The longer life cycle of the LED-UV lamps and lower energy demands for cooling to maintain temperature at a level suitable for bacterial growth are excepted to reduce energy inputs. In addition, the UVA used to induce photolysis in the NBB does not induce damage to the bacterial 
Table 2 Bacterial strains identified as present in the NBB, and the presence of functional genes related to BDE-209 biodegradation during coupled UV phytolysis-biodegration process

\begin{tabular}{|c|c|c|c|c|c|c|c|c|c|c|c|}
\hline \multirow{3}{*}{$\begin{array}{c}\text { Strain } \\
\text { No. } \\
\\
\text { UV-A }\end{array}$} & \multirow{3}{*}{$\begin{array}{c}\text { Bacterial strains } \\
\text { (NCBI Similarity } \\
\text { Identification) }\end{array}$} & \multicolumn{3}{|c|}{$\begin{array}{l}\text { Utilization of PBDEs } \\
\text { as carbon source }\end{array}$} & \multicolumn{7}{|c|}{$\begin{array}{c}\text { Response to target primers with } \\
\text { functional genes related to BDE- } \\
209 \text { biodegradation } \\
\end{array}$} \\
\hline & & \multirow{2}{*}{$\begin{array}{c}\text { BDE- } \\
209 \\
4 \\
\end{array}$} & \multirow{2}{*}{$\begin{array}{c}\begin{array}{c}\text { BDE- } \\
\mathbf{1 5}\end{array} \\
1 \\
\end{array}$} & \multirow{2}{*}{$\begin{array}{c}\text { Mixed } \\
\text { 38 PBDEs } \\
\\
1\end{array}$} & \multicolumn{2}{|c|}{ C23O ARHD } & \multicolumn{3}{|c|}{ Rf RdhA RDase } & \multicolumn{2}{|c|}{$\begin{array}{c}\text { TCEse } \\
\text { PceA } \\
\text { (Negative } \\
\text { control) }\end{array}$} \\
\hline & & & & & + & + & - & + & - & - & - \\
\hline UV-B & Paracoccus yeei $(97 \%)$ & 2 & 1 & 1 & - & - & - & - & - & - & - \\
\hline UV-C & Microbacterium sp. (97\%) & 4 & 0 & 0 & - & - & - & - & - & - & - \\
\hline UV-D & $\begin{array}{c}\text { Pseudomonas geniculate } \\
(98 \%)\end{array}$ & 4 & 0 & 0 & + & - & + & - & - & & - \\
\hline UV-E & $\begin{array}{c}\text { Microbacterium } \\
\text { laevaniformans }(97 \%)\end{array}$ & 3 & 1 & 1 & - & - & - & - & - & & - \\
\hline UV-F & $\begin{array}{c}\text { Stenotrophomonas sp. } \\
(98 \%)\end{array}$ & 3 & 1 & 1 & + & + & + & + & + & & - \\
\hline UV-G & $\begin{array}{c}\text { Stenotrophomonas sp. } \\
(97 \%)\end{array}$ & 3 & 1 & 1 & + & - & + & - & - & & - \\
\hline UV-H & $\begin{array}{c}\text { Pseudomonas stutzeri } \\
(96 \%)\end{array}$ & 2 & 2 & 0 & + & - & - & + & - & & - \\
\hline UV-I & Pseudomonas sp. (97\%) & 4 & 0 & 0 & + & - & - & + & - & - & - \\
\hline $\begin{array}{l}\text { UV-J } \\
\end{array}$ & Pseudomonas sp. (97\%) & 4 & 3 & 4 & + & - & 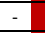 & + & - & - & - \\
\hline UV-K & $\begin{array}{c}\text { Pseudomonas stutzeri } \\
(97 \%)\end{array}$ & 4 & 1 & 4 & + & + & & + & - & - & - \\
\hline
\end{tabular}

0: No reaction

1: Weak reaction

2: Medium reaction

3: Strong reaction

4: Very strong reaction

DNA to a significant degree because it is not absorbed by native DNA. The acclimated UV-resistant bacteria in the NBB are highly capable of BDE-209 utilization; they grow well in the NBB, biodegrading BDE-209, PBDEs and OHPBDEs. Furthermore, the heat generated by LED-UV irradiation helps maintain a steady temperature (on average $31^{\circ} \mathrm{C}$ ) in the NBB thereby enhancing the rate and extent of BDE-209 biodegradation in the clay/water system evaluated. The firstorder-rate constant $(k)$ for BDE-209 biodegradation compared by coupled UV photolysis and biodegradation in the NBB was $1.31 \times 10^{-2} \mathrm{day}^{-1}$, which is greater than that observed for a batch experiment where dark-brown glass serum bottles where used and biodegradation was combined with UV irradiation at room temperature $\left(k=1.29 \times 10^{-2}\right.$ day $\left.^{-1}\right)$ (Chou et al. 2013).

Sequential UVB photolysis-biodegradation process was shown previously effectively remove BDE-209 using a clay/ water system (Chang et al. 2020). Overall, the sequential process is a more effective design than the coupled UV photolysisbiodegradation process (described herein) or biodegradation alone when the processes are evaluated using their rates of BDE-209 degradation. The first-order rate constants $(k)$ are as follows: sequential UVB photolysis-biodegradation process $(k$ $=0.026$ day $\left.^{-1}\right)>$ coupled LED-UVA photolysis-biodegradation process $\left(k=0.013 \mathrm{day}^{-1}\right)>$ biodegradation alone $(k=$ 0.010 day $\left.^{-1}\right)$. The UVB irradiation treatment with high energy intensity was intended to generate more free radicals that cleave C-Br bonds of BDE-209 present in the clay/water slurry system (Eriksson et al. 2004). The molar absorptivity of PBDEs in the
UVB region is much greater than that in the UVA region (Pan et al. 2016). Therefore, the higher rate constant for BDE-209 degradation in the clay/water system by photolysis with UVB irradiation $\left(0.017 \mathrm{day}^{-1}\right)$ as compared to photolysis by UVA irradiation $\left(0.011 \mathrm{day}^{-1}\right)$ could plausibly indicate greater formation of OH-PBDE and PBDE intermediates in the former case (UVB photolysis) which would be more susceptible to biodegradation including use as a carbon source and/or as an alternative carbon source via co-metabolism. Pretreatment of highmolecule-weight aromatic PAH mixtures, containing anthracene, pyrene, benz $[\mathrm{a}]$ anthracene, and dibenz $[\mathrm{a}, \mathrm{h}]$ anthracene, with UV irradiation was shown to accelerate biodegradation by an enriched culture of a Sphingomonas sp. and S. yanoikuyae (Lehto et al. 2003). Potential disadvantages of the sequential UVB photolysis-biodegradation process compared to the coupled UVA photolysis-biodegradation process are the need for extra time to transfer the clay/water system from the first-stage UVB photolysis system into the secondstage system for biodegradation, and secondly the amount of energy required for UVB irradiation is greater than that required for continuous LED UVA irradiation. Furthermore, the coupled LED UVA photolysis-biodegradation process used here to successfully treat BDE-209 is an energy and costsaving approach. The NBB is designed to have cooling fins and is able to recycle most of waste energy produced during the continuous UVA irradiation as heat loss and thus the system is able to maintain the steady temperature required for bacterial degradation. The UV-resistant bacteria present in the reactor are therefore able to accelerate the removal of BDE-209 and its intermediates by photolysis/biodegradation in parallel within the NBB. The advantages of this system mean that the NBB should be able to able to decompose other POPs/ECs and therefore will be very useful for the remediation of a wide range of contaminated environments and ecological system.

\section{Bacterial strains isolated from the NBB system are involved in PBDEs biodegradation}

Bacterial strains isolated from the NBB operating with coupled BDE-209-biodegradation have the established ability to utilize PBDEs and/or a variety of other aromatic compounds. For example, Pseudomonas aeruginosa has been shown to be involved in the aerobic debromination of BDE209. Evaluation of biodegradation intermediates showed that $P$. aeruginosa degraded BDE-209 into lower brominated PBDEs and OH-PBDEs through debromination and hydroxylation of the aromatic rings (Liu et al. 2019). Furthermore, $P$. stutzeri has been shown to utilize BDE-47 as a sole carbon source and achieved almost complete $(97.94 \%)$ biodegradation during a two-week incubation (Zhang et al. 2013b). Mycobacterium spp., which are distributed widely in soils, have the ability to biodegrade aromatic pesticides and contaminants, such as the acetanilide herbicides (e.g., propanil) and 
benzo(a)pyrene (Hou et al. 2015; Qin et al. 2017). Microbacterium sp. have been shown to biodegrade BDE-47 as sole carbon source under aerobic condition (Zhang et al. 2013a). A Stenotrophomonas strain isolated from soils at a PBDEs-contaminated e-waste recycling site was able to effectively degrade BDE-209 (55.15\% of $\left.65 \mu \mathrm{g} \mathrm{l}^{-1}\right)$ under aerobic conditions during a 30-day incubation (Wu et al. 2018), and Paracoccus yeei has been shown to utilize benzo[a]pyrene as a sole carbon and energy source (Sowada et al. 2014).

UVA irradiation can adversely affect microbial activity and hence inhibit biochemical reactions in the NBB. Figure 3 shows that the number of bacteria present during the coupled UV photolysis-biodegradation process is less than for biodegradation alone. UVA light has been reported to generate singlet oxygen $\left({ }^{1} \mathrm{O}_{2}\right)$ that can damage bacterial DNA via indirect photosensitization reactions (Rastogi et al. 2010). However, the microbial community within the BDE-209-clay/water system has been reported to have a high tolerance for continuous UVA irradiation, as well as the ability to bring about PBDEs biodegradation (Chang et al. 2019). Pseudomonas spp., Microbacterium spp., and Stenotrophomonas spp. have all been identified as being involved in BDE-209 biodegradation under continuous UVA irradiation in the NBB, and these are known to be radiation resistant bacteria. Specifically, they are usually able to express enzymes capable of repairing the damaged DNA created by irradiation and thus are able to survive high levels of radiation. Specific chemicals, such as ectoine from Stenotrophomonas spp., have been shown to overcome radiation-mediated oxidative damage in an extreme UV irradiation environment (Sajjad et al. 2018).

\section{The mechanisms of BDE-209 degradation present in the NBB system}

A possible pathway for BDE-209 degradation by coupled UV photolysis and biodegradation is shown in Fig. 5. This is based on several lines of evidences: (1) the intermediates detected during our study; (2) the release of bromide from BDE209, and (3) presence of genes encoding functional enzymes related to BDE-209 biodegradation. Various degradation intermediates, such as PBDE congeners, OH-PBDEs, PBDFs, and bromide, are generated by a complex series of photolytic and biological reactions within the clay-water slurries of the NBB system. Consecutive reductive debromination with intramolecular elimination of $\mathrm{HBr}$ is a predominant pathway associated with solid phase PBDEs photolysis (Pan et al. 2016). In the present study, spontaneous debromination is known to occur during UV photolysis of intermediates following ring cleavage of PBDEs. Higher brominated PBDEs, e.g., BDE-209, can absorb long wavelength $365 \mathrm{~nm}$-UVA light and undergo consecutive debrominated to give lower brominated PBDEs, which are relatively more soluble in clay-water slurries. The accumulation of lower brominated BDE-99 and
BDE-47 in the NBB also occurs during the photolytic debromination of BDE-209 in soils (Söderström et al. 2004). Moreover, the formation of PBDFs can occur via the intramolecular elimination of $\mathrm{HBr}$ from either lower brominated PBDEs or OH-PBDEs which are also formed by homolytic $\mathrm{C}-\mathrm{O}$ bond cleavage of lower brominated PBDEs. However, it should be noted that PBDF derivatives have disappeared by the end of the present experiment (day 120), which supports the notion that there are multiple reactions and coupled processes involving UV photolysis and aerobic biodegradation occurring within the reactors and that bring about the removal of PBDFs.

Aerobic biodegradation of lower brominated PBDEs and OH-PBDEs has been shown to involve several mechanisms. First, cleavage of the aromatic rings of lower brominated PBDEs occurs via a series of reactions involving hydroxylation. Alternatively, the cleavage of benzene rings might occur in various different bacterial species under aerobic conditions, based on the presence of positive signals for genes encoding various dioxygenases. Thus, bromine substituents of the lower brominated PBDEs could be substituted for by an $\mathrm{OH}$ group (via hydroxylation) thus generating hydroxylated biometabolites. Genes encoding a number of dioxygenases, such as C23O, ARHD, and Rf, are known to be involved in the biodegradation of aromatic hydrocarbons by the various bacterial species that have been identified in this study (Table 1). These dioxygenases employ different approaches when utilizing BDE-209 and its degradation intermediates. Positive PCR reactions for these dioxygenases during coupled UV photolysis/biodegradation suggest that these different enzymes are involved in the aerobic biodegradation of BDE-209, including the oxidative cleavage of PBDEs and other metabolites such as catechol. This hypothesis is supported, firstly, by the fact that a wide variety of $\mathrm{C} 23 \mathrm{O}$ genes are present in the NBB bacterial species identified with the reactor. These $\mathrm{C} 23 \mathrm{O}$ enzymes are known to bring about meta-cleavage at specific unbrominated ring positions, and have also been identified as present during BDE-209 biodegradation in a soil slurry microcosm (Chou et al. 2016). An increase in expression of between 30-fold and 3,000-fold has been found for biphenyl and ethylbenzene dioxygenases during the biotransformation of monoBDE through to penta-BDE congeners (Robrock et al. 2011). Moreover, the ARHD genes are able to degrade polychlorinated biphenyls (PCB), which have a chemical structure similar to the PBDE congeners detected in the present study. These enzymes consist of ring hydroxylation dioxygenases that have cysteine and histidine residues coordinated with a $2 \mathrm{Fe}-2 \mathrm{~S}$ cluster, as well as hydroxylation dioxygenases (Kitagawa et al. 2001). Rf genes encode the larger $\alpha$-subunit of a terminal dioxygenase. This gene has been used as an oxygenase indicator when there is aromatic substrate specificity and when dioxygenase activity is the rate-limiting step. The $\alpha$-subunit amplified here is the catalytic component 
Fig. 5 Proposed pathways for coupled UV irradiation-

biodegradation process used for BDE-209 treatment in the NBB

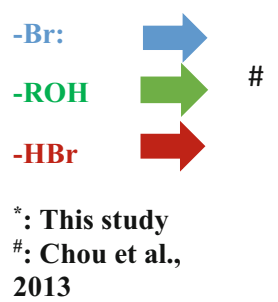

and contains two conserved regions, namely the $\left[\mathrm{Fe}_{2}-\mathrm{S}_{2}\right]$ Riseker center and the mononuclear iron binding domain. These two centers have been shown to be involved in consecutive electron transfer to dioxygen molecules (Yu et al. 2019a).

In addition, it is plausible that biological reductive debromination is occurring in the reactor because there are positive signals for genes encoding dehalogenases, and this enzymatic reaction is known to generate significant amounts of bromide. Dehalogenation is the key step in the biodegradation of halogenated aromatics. Various dehalogenases, such as

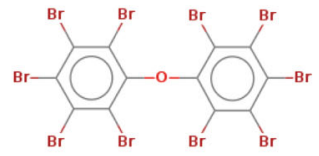

Decabrominated diphenyl

\#
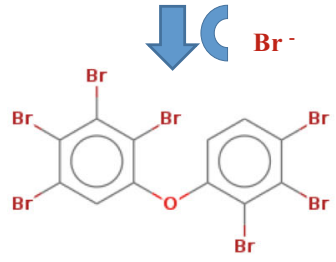

Heptabromodiphenyl ether

*

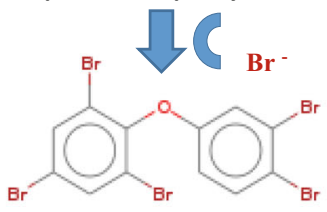

Penabromodiphenyl ether

$\left(2,2^{\prime}, 4,4^{\prime}, 5\right.$-Pentabromodiphenyl ether)

*

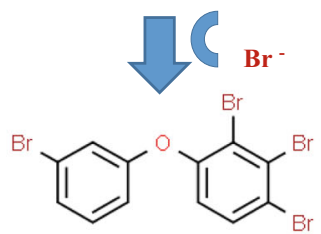

Tetrabromodiphenyl ether
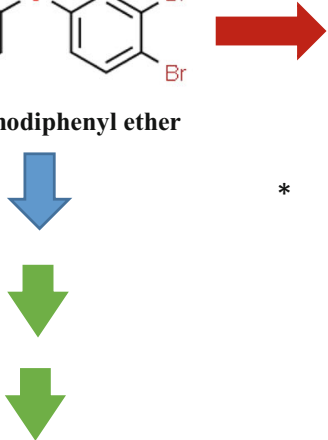<smiles>Brc1ccc2oc3ccc(Br)cc3c2c1</smiles>

2,8-dibromodibenzofuran
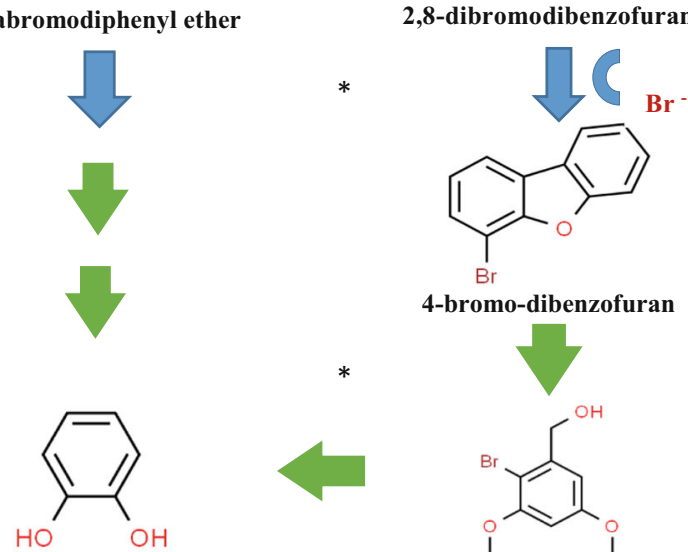

1,2-Benzenediol
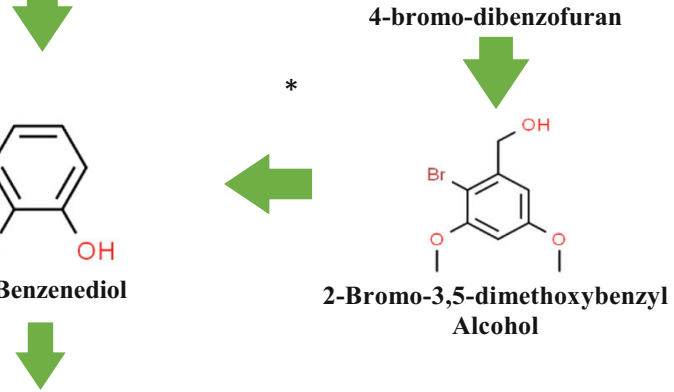

TCA cycle
RdhA and Rdase, have been shown to be involved in the aerobic dehalogenation of aromatic organohalide compounds (Arora and Bae 2014). Three bacterial species identified in the present study, Pseudomonas spp. (UV-H, UV-I, UV-J and UV-J), Stenotrophomonas sp. (UV-F) and Microbacterium sp. (UV-A), are known to be involved in the biodegradation of halogenated aromatic hydrocarbons. One enzyme responsible for catalyzing organohalide respiration under aerobic conditions is reductive dehalogenase (Rdase). Rdase $\mathrm{c}$ of a cobalamin centered catalytic subunit A (RdhA) and a 
membrane anchoring subunit B. Genes encoding Rdase and RdhA are likely to be involved in the reductive debromination of BDE-209 by the various aerobic/facultative anaerobic bacterial species identified in this study. RdhA proteins have several conserved domains, including two iron-sulfur [4Fe-4S] cluster-binding motifs and a twin-arginine signal motif that is used for translocation to or translocation across the cell membrane (Hug and Edwards 2013). One aerobic Gram negative bacteria, Comamonas sp. 7D-2, has been shown to be able to completely degrade the brominated aromatic herbicide bromoxynil, and in the process it releases two equivalents of bromide; this was carried out under aerobic conditions and a specific Rdase was identified. This enzyme has key features in common with the anaerobic respiratory RdhAs, such as a complex of a RdhA domain and a NAD(P)H-dependent oxidoreductase domain (Chen et al. 2013). Finally, a microbial consortium, including three of our identified species, i.e., Microbacterium sp., Stenotrophomonas sp., and Pseudomonas sp., has been shown previously to encode RdhA genes capable of aerobic BDE-209 biodegradation (Yu et al. 2019b).

In the model described above, BDE-209 degradation occurs by UV irradiation and biodegradation during the coupled UVA photolysis-biodegradation process. The rate of bromide generation by photolysis alone $\left(0.63 \mathrm{mg} \mathrm{L}^{-1}\right.$ day $\left.^{-1}\right)$ is faster than by biodegradation alone $\left(0.14 \mathrm{mg} \mathrm{L}^{-1}\right.$ day $\left.^{-1}\right)$ indicating that the process of chemical debromination is faster than the biological debromination. Thus, UV photolysis in the NBB might include the major process by which PBDEs, especially BDE-209, are initially decomposed. Specifically, chemical debromination will plausibly break the $\mathrm{Br}-\mathrm{C}$ bonds of BDE209 effectively when significant amounts of free radicals are being created by UV irradiation resulting in less BDE-209 being biodegraded by the Da-An bacterial community. A previous study measured the rates of breakdown of a mixture of fifteen PBDEs by photolysis. When the rates for higher brominated PBDEs were compared to those for lower brominated PBDEs (Eriksson et al. 2004), the rate of BDE-209 degradation $\left(4 \times 10^{6}, \mathrm{~s}^{-1}\right)$ was a 100 fold higher than that of BDE-155 degradation $\left(4.1 \times 10^{4}, \mathrm{~s}^{-1}\right)$ and was 570 fold higher than that of BDE-47 $\left(7.0 \times 10^{3}, \mathrm{~s}^{-1}\right)$.

\section{Conclusion}

This study developed a coupled LED UVA photolysisbiodegradation process in a NBB and in the process successfully maximized the degradation rate of the BDE-209 present in a clay-water slurry, compared to either UV photolysis alone or biodegradation alone. The NBB was designed so that the multiple chemical/biological reactions brought about by UV photolysis and biodegradation occur together in synergy. The major derivatives created by this system during the decomposition of BDE-209 include OH-PBDEs, lower brominated PBDE congeners, PBDFs, and significant amounts of bromide. The prediction of a possible pathway for BDE-209 degradation via coupled photolysis-biodegradation was developed, based on the above-mentioned intermediates. Specific UV-resistant bacterial strains, e.g., Stenotrophomonas sp., Pseudomonas sp., and Microbacterium sp., were identified during the coupled UV-biodegradation process and these strains potentially have the ability to utilize BDE-209 as a sole carbon source. Since the chemical structure of PBDEs consists of two aromatic benzene rings with different numbers of bromides, this structure is vulnerable to sequential benzene ringcleavage reactions by various dioxygenases. The presence of ring-cleavage oxygenases such as $\mathrm{C} 23 \mathrm{O}$ and dehalogenases such as RdhA in this aerobic system opens up possibilities for basic research into these enzymes. Furthermore, these enzymes have a wide potential applications as part of an integrated remediation system for PBDEs. The results presented here provide the basis for an effective green remediation technology for the treatment of POPs/ECs when they are associated with soil geosorbents. Our findings provide a good starting point for the development of an ex situ integrated remediation system that couples UV photolysis with biodegradation and that is able to degrade BDE-209 effectively. Future studies using whole soils and other recalcitrant POPs/ ECs are needed to broaden the application of this promising technology. In addition during such analyses, changes in expression levels of the various functional genes associated with and related to BDE-209 biodegradation need to be quantified by qPCR.

Funding This study is supported by project grants from Taiwan MOST, grant number MOST104-2815-C-031-040-E and MOST108-2918-I031-001.

\section{Compliance with ethical standards}

Conflict of interest The authors declare that they have no conflict of interest.

\section{References}

Alfreider A, Vogt C, Babel W (2003) Expression of chlorocatechol 1, 2dioxygenase and chlorocatechol 2,3-dioxygenase genes in chlorobenzene-contaminated subsurface samples. Appl Environ Microbiol 69:1372-1376

Arora PK, Bae H (2014) Role of dehalogenases in aerobic bacterial degradation of chlorinated aromatic compounds. J Chem 2014. https:// doi.org/10.1155/2014/157974

Chang Y-T, Chou H-L, Li H, Boyd SA (2019) Variation of microbial communities in aquatic sediments under long-term exposure to decabromodiphenyl ether and UVA irradiation. Sustainability 11: 3773

Chang Y-T, Chao W-L, Chen H-Y, Li H, Boyd SA (2020) Characterization of a sequential UV photolysis-biodegradation 
process for treatment of decabrominated diphenyl ethers in sorbent/ water systems. Microorganisms 8:633

Chen K, Huang L, Xu C, Liu X, He J, Zinder SH, Li S, Jiang J (2013) Molecular characterization of the enzymes involved in the degradation of a brominated aromatic herbicide. Mol Microbiol 89:1121-1139

Chou H-L, Chang Y-T, Liao Y-F, Lin CH (2013) Biodegradation of decabromodiphenyl ether (BDE-209) by bacterial mixed cultures in a soil/water system. Int Biodeterior Biodegradation 85:671-682

Chou H-L, Hwa M-Y, Lee Y-C, Chang Y-J, Chang Y-T (2016) Microbial degradation of decabromodiphenyl ether (DBDE) in soil slurry microcosms. Environ Sci Pollut Res Int 23:5255-5267

Eriksson J, Green N, Marsh G, Bergman Å (2004) Photochemical decomposition of 15 polybrominated diphenyl ether congeners in methanol/water. Environ Sci Technol 38:3119-3125

Holmes VF, He J, Lee PKH, Alvarez-Cohen L (2006) Discrimination of multiple Dehalococcoides strains in a trichloroethene enrichment by quantification of their reductive dehalogenase genes. Appl Environ Microbiol 72:5877-5883

Hou Y, Li S, Dong W, Yuan Y, Wang Y, Shen W, Cui Z (2015) Community structure of a propanil-degrading consortium and the metabolic pathway of Microbacterium sp. strain T4-7. Int Biodeterior Biodegradation 105:80-89

Hug LA, Edwards EA (2013) Diversity of reductive dehalogenase genes from environmental samples and enrichment cultures identified with degenerate primer PCR screens. Front Microbiol 4:Article 341

Ji X, Ding J, Xie X, Cheng Y, Huang Y, Qin L, Han C (2017) Pollution status and human exposure of decabromodiphenyl ether (BDE-209) in China. ACS Omega 2:3333-3348

Kitagawa W, Suzuki A, Hoaki T, Masai E, Fukuda M (2001) Multiplicity of aromatic ring hydroxylation dioxygenase genes in a strong PCB degrader, Rhodococcus sp. strain RHA1 demonstrated by denaturing gradient gel electrophoresis. Biosci Biotechnol Biochem 65:1907-1911

Krajmalnik-Brown R, Hölscher T, Thomson IN, Saunders FM, Ritalahti KM, Löffler FE (2004) Genetic identification of a putative vinyl chloride reductase in Dehalococcoides sp. strain BAV1. Appl Environ Microbiol 70:6347-6351

Kumar A, Kumar S, Kumar S (2005) Biodegradation kinetics of phenol and catechol using Pseudomonas putida MTCC 1194. Biochem Eng J 22:151-159

Lehto K-M, Puhakka JA, Lemmetyinen H (2003) Biodegradation of selected UV-irradiated and non-irradiated polycyclic aromatic hydrocarbons (PAHs). Biodegradation 14:249-263

Liu H, Hu W, Sun H, Shen O, Wang X, Lam MH, Giesy JP, Zhang X, Yu $\mathrm{H}$ (2011) In vitro profiling of endocrine disrupting potency of 2, 2', 4, 4'-tetrabromodiphenyl ether (BDE47) and related hydroxylated analogs (HO-PBDEs). Mar Pollut Bull 63:287-296

Liu Y, Liu Z, Gong A, Qiu L, Zhang W, Li J, Li F, Bai Y, Li J, Gao G (2019) Cell changes and differential proteomic analysis during biodegradation of decabromodiphenyl ether (BDE-209) by Pseudomonas aeruginosa. RSC Adv 9:25048-25055

McGrath TJ, Ball AS, Clarke BO (2017) Critical review of soil contamination by polybrominated diphenyl ethers (PBDEs) and novel brominated flame retardants (NBFRs); concentrations, sources and congener profiles. Environ Pollut 230:741-702

Noyes PD, Lema SC, Macaulay LJ, Douglas NK, Stapleton HM (2013) Low level exposure to the flame retardant BDE-209 reduces thyroid hormone levels and disrupts thyroid signaling in fathead minnows. Environ Sci Technol 47:10012-10021

Pan Y, Tsang DCW, Wang Y, Li Y, Yang X (2016) The photodegradation of polybrominated diphenyl ethers (PBDEs) in various environmental matrices: kinetics and mechanisms. Chem Eng Sci 297:74-96

Qin W, Zhu Y, Fan F, Wang Y, Liu X, Ding A, Dou J (2017) Biodegradation of benzo(a)pyrene by Microbacterium sp. strain under denitrification: degradation pathway and effects of limiting electron acceptors or carbon source. Biochem Eng J 121:131-138
Rastogi RP, Richa, Kumar A, Tyagi MB, Sinha RP (2010) Molecular mechanisms of ultraviolet radiation-induced DNA damage and repair. J Nucleic Acids 2010. https://doi.org/10.4061/2010/592980

Robrock KR, Mohn WW, Eltis LD, Alvarez-Cohen L (2011) Biphenyl and ethylbenzene dioxygenases of Rhodococcus jostii RHA1 transform PBDEs. Biotechnol Bioeng 108:313-321

Sajjad W, Qadir S, Ahmad M, Rafiq M, Hasan F, Tehan R, McPhail KL, Shah AA (2018) Ectoine: a compatible solute in radio-halophilic Stenotrophomonas sp. WMA-LM19 strain to prevent ultraviolet-induced protein damage. J Appl Microbiol 125:457-467

Schlötelburg C, von Wintzingerode C, Hauck R, von Wintzingerode F, Hegemann W, Göbel UB (2002) Microbial structure of an anaerobic bioreactor population that continuously dechlorinates 1,2dichloropropane. FEMS Microbiol Ecol 39:229-237

Segev O, Kushmaro A, Brenner A (2009) Environmental impact of flame retardants (persistence and biodegradability). Int J Environ Res Public Health 6:478-491

Shan MP (2013) Combined application of biological-photocatalytic process in degradation of reactive black dye: an excellent outcome. Am J Microbiol Res 1:92-97

Shan S, Zhang Y, Zhang Y, Hui L, Shi W, Zhang Y, Rittmann BE (2017) Comparison of sequential with intimate coupling of photolysis and biodegradation for benzotriazole. Front Environ Sci Eng 11:8

Söderström G, Sellström U, de Wit CA, Tysklind M (2004) Photolytic debromination of decabromodiphenyl Ether (BDE 209). Environ Sci Technol 38:127-132

Sowada J, Schmalenberger A, Ebner I, Luch A, Tralau T (2014) Degradation of benzo[a]pyrene by bacterial isolates from human skin. FEMS Microbiol Ecol 88:129-139

Suyama A, Yamashita M, Yoshino S, Furukawa K (2002) Molecular characterization of the PceA reductive dehalogenase of Desulfitobacterium sp. Strain Y51. J Bacteriol 184:3419-3428

Taha M, Krishna K, Al-Hothaly K, Smith AT, Ball AS, Adetutu EM (2015) An effective microplate method (Biolog MT2) for screening native lignocellulosic-straw-degrading bacteria. Ann Microbiol 65: 2053-2064

Wang Y, Chen T, Sun Y, Zhao X, Zheng D, Jing L, Zhou X, Sun Z, Shi Z (2019) A comparison of the thyroid disruption induced by decabrominated diphenyl ethers (BDE-209) and decabromodiphenyl ethane (DBDPE) in rats. Ecotoxicol Environ Saf 174:224-235

Wu Z, Xie M, Li Y, Gao G, Bartlam M, Wang Y (2018) Biodegradation of decabromodiphenyl ether (BDE 209) by a newly isolated bacterium from an e-waste recycling area. AMB Express 8:27

Yu C-C, Chang T-C, Liao C-S, Chang Y-T (2019a) A comparison of the microbial community and functional genes present in free-living and soil particle-attached bacteria from an aerobic bioslurry reactor treating high-molecular-weight PAHs. Sustainability 11:1088

Yu Y, Yin H, Peng H, Lu G, Dang Z (2019b) Biodegradation of decabromodiphenyl ether (BDE-209) using a novel microbial consortium GY1: cells viability, pathway, toxicity assessment, and microbial function prediction. Sci Total Environ 668:958-965

Zhang D, Li W, Huang X, Qin W, Liu M (2013a) Removal of ammonium in surface water at low temperature by a newly isolated Microbacterium sp. strain SFA13. Bioresour Technol 137:147-152

Zhang S, Xia X, Xia N, Wu S, Gao F, Zhou W (2013b) Identification and biodegradation efficiency of a newly isolated $2,2^{\prime}, 4,4$ ' tetrabromodiphenyl ether (BDE-47) aerobic degrading bacterial strain. Int Biodeterior Biodegradation 76:24-31

Publisher's note Springer Nature remains neutral with regard to jurisdictional claims in published maps and institutional affiliations. 